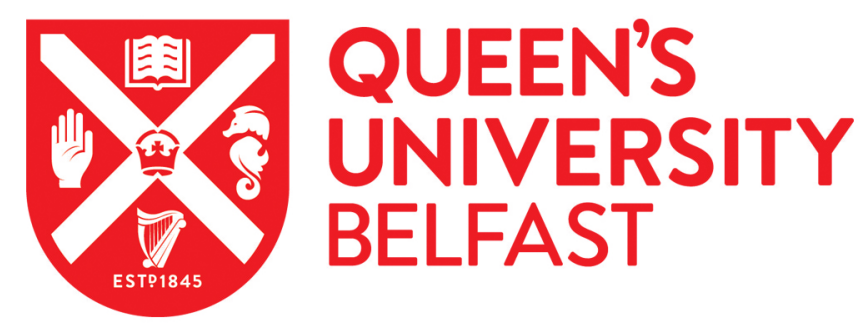

\title{
Assessing the distribution of social-ecological resilience and risk: Ireland as a case study of the uneven impact of famine
}

Flaherty, E. (2014). Assessing the distribution of social-ecological resilience and risk: Ireland as a case study of the uneven impact of famine. Ecological Complexity, 19, 35-45. https://doi.org/10.1016/j.ecocom.2014.04.002

\author{
Published in: \\ Ecological Complexity
}

\section{Document Version:}

Peer reviewed version

Queen's University Belfast - Research Portal:

Link to publication record in Queen's University Belfast Research Portal

\begin{abstract}
Publisher rights
Copyright 2014 Elsevier B.V. All rights reserved.

This is the author's version of a work that was accepted for publication in Ecological Complexity. Changes resulting from the publishing process, such as peer review, editing, corrections, structural formatting, and other quality control mechanisms may not be reflected in this document. Changes may have been made to this work since it was submitted for publication. A definitive version was subsequently published in Ecological Complexity, volume 19, September 2014, doi:10.1016/j.ecocom.2014.04.002.

\section{General rights}

Copyright for the publications made accessible via the Queen's University Belfast Research Portal is retained by the author(s) and / or other copyright owners and it is a condition of accessing these publications that users recognise and abide by the legal requirements associated with these rights.
\end{abstract}

Take down policy

The Research Portal is Queen's institutional repository that provides access to Queen's research output. Every effort has been made to ensure that content in the Research Portal does not infringe any person's rights, or applicable UK laws. If you discover content in the Research Portal that you believe breaches copyright or violates any law, please contact openaccess@qub.ac.uk. 


\title{
Assessing the distribution of social-ecological resilience and risk: Ireland as a case study of the uneven impact of famine
}

\author{
Dr. Eoin Flaherty \\ School of Sociology, Social Policy and Social Work \\ Queen’s University Belfast
}

Acknowledgement: The research for this article was funded by the Irish Research Council. Special thanks to Dr. Eamonn Slater, Department of Sociology, National University of Ireland Maynooth

Keywords: resilience, cluster analysis, Ireland, famine, entitlement, regime

\begin{abstract}
Explanations for the causes of famine and food insecurity often reside at a high level of aggregation or abstraction. Popular models within famine studies have often emphasised the role of prime movers such as population stress, or the political-economic structure of access channels, as key determinants of food security. Explanation typically resides at the macro level, obscuring the presence of substantial within-country differences in the manner in which such stressors operate. This study offers an alternative approach to analysing the uneven nature of food security, drawing on the Great Irish famine of 1845-1852. Ireland is often viewed as a classical case of Malthusian stress, whereby population outstripped food supply under a pre-famine demographic regime of expanded fertility. Many have also pointed to Ireland's integration with capitalist markets through its colonial relationship with the British state, and country-wide system of landlordism, as key determinants of local agricultural activity. Such models are misguided, ignoring both substantial complexities in regional demography, and the continuity of non-capitalistic, communal modes of land management long into the nineteenth century. Drawing on resilience ecology and complexity theory, this paper subjects a set of aggregate data on pre-famine Ireland to an optimisation clustering procedure, in order to discern the potential presence of distinctive social-ecological regimes. Based on measures of demography, social structure, geography, and land tenure, this typology reveals substantial internal variation in regional social-ecological structure, and vastly differing levels of distress during the peak famine months. This exercise calls into question the validity of accounts which emphasise uniformity of structure, by revealing a variety of regional regimes, which profoundly mediated local conditions of food security. Future research should therefore consider the potential presence of internal variations in resilience and risk exposure, rather than seeking to characterise cases based on singular macro-dynamics and stressors alone.
\end{abstract}

\section{Introduction: resource security, social structure, and the uneven impact of famine}

Human suffering throughout periods of famine is rarely due to lack of food alone. Causes of food insecurity arise not only from inadequacies in food availability and supply channels, but from numerous social factors, such as regional and international trade relations, demographic and agrarian structures, land tenures, political systems and conflicts, and domestic market conditions. Within countries, the experience of famine is rarely uniform, and its uneven geographical impact calls into question the validity of food security analyses based on dominant variables alone. Famine research has long criticised models of food security based 
on 'de-contextualised Malthusianism', which depict famines as a consequence of population growth outstripping food production (Hughes, 2000). In response, a number of frameworks have emerged in recent decades which have examined resource security, not as a product of destabilising variables such as population growth, but as a result of political-economic failures, or patterns of cumulative risk exposure specific to the nature of local ecosystems.

Within the social sciences, Amartya Sen's entitlements framework offers one of the most potent challenges to Malthusianism in studies of food security (1976, 1980, 1981). Sen's approach focuses not only on direct food availability, but also on the various productive, and political-economic channels (entitlements), through which populations may secure food. Insecurity and famine thus result from a cumulative collapse of entitlements, where food supply is disrupted by an inability to grow subsistence food (direct entitlements), an inability to exchange labour or property on the market (indirect entitlements), or an absence of adequate systems of public relief and social security (transfer entitlements). In combination, the presence of functioning entitlement channels lowers the probability of a population's exposure to resource scarcity, and variations in local famine severity may be explained in terms of their presence or absence.

Environmental sociology has been slow to respond to the project of integrating both ecological and social variables in human-coupled ecosystems analysis however, focusing instead on the realms of culture and discourse. Much debate within sociology on naturalsocial integration has centred on delineating the social as a distinct object of scientific investigation; as a result, much research has focused specifically on the roles of culture and knowledge. Some have critically analysed the centrality of scientific knowledge in public discourse, whilst others working within the rubric of Actor-Network Theory have focused on developing alternative, 'co-constructivist' theoretical models of the relationship between nature and society (Dickens, 1996; Latour, 2004, 2005; Murdoch, 2001; Yearley, 2005). Although these approaches offer valuable insight into the public framing of ecological issues, the cultural underpinnings of land-use patterns, and the social-systemic foundations of environmental impact, they offer less to directly inform empirical analyses of the distribution of food security.

More recently, researchers drawing on the interdisciplinary framework of resilience ecology have reasserted the importance of social structure (Adger, 2000; Holling, 2001; Janssen, Anderies and Ostrom, 2007; Walker et al., 2006). These authors have suggested focusing on the social-ecological characteristics of food production systems themselves, in order to explain the causes of resource insecurity in specific contexts. (Abel, Cumming and Andrews, 2006; Berkes, Colding and Folke, 2003; Cumming et al., 2005; Fraser 2006, 2007; van Apeldoon et al., 2011). Contrasted with engineering resilience as a measure of a systems' return to its 'base state' following disturbance, ecological resilience assesses the amount of disturbance a system may undergo before transition to an alternate state is induced (Gunderson, 2003). The probability of a particular system crossing this threshold is determined by its adaptive capacity, or its ability to appropriately respond to feedback (Berkes, Colding and Folke, 2003; Fabricius and Cundill, 2011; Matthews and Sydneysmith, 2011). The utility of an ecological resilience approach, as opposed to a 'stability' or engineering resilience approach, rests in its use of the concepts of regime and identity, as opposed to equilibrium and structure. A regime may be conceptualised as a '...locally stable or self-reinforcing set of conditions...the dominant set of drivers and feedbacks that lead to system behaviour' (Cumming, 2011: 14). Specific social-ecological systems may be 
conceptualised as particular assemblages of institutions and structures, constituting a particular identity (ibid).

Ireland is a country which offers an ideal testing ground for the analytical potential of a resilience approach. The Great Irish Famine of 1845-1852 has been described as the '...last great subsistence crisis of the Western world' (Kennedy and Clarkson, 1993: 158), with mortality estimates ranging from 800,000 (Cousens, 1960), to 1,000,000-1,500,000 (Mokyr, 1980 ), or $9.8 \%-18.3 \%$ of total population. As with other cases of famine, it has proven difficult to ascertain the proportions of population decline attributable to starvation, death by disease, or emigration respectively, although Boyle and Ó’ Gráda estimate a population loss due to excess death of 981,000 throughout the famine period (1986: 555). To date, little attention has been given to the social factors underpinning spatial variations in the experience of famine, much less the manner in which local conditions mediated the experience of distress throughout this period. Much existing work has placed the blame for the Great Irish Famine on singular causes, such as its rapid population expansion, trade relations with Britain, or extensive reliance on potato-based subsistence agriculture (Bourke, 1959; Downey, 1996). Many of these claims are misguided, serving only to obscure the existence of internal variations in social-ecological structure within Ireland at this time, and the multiple causal pathways giving rise to differing levels of distress across regions.

This study seeks to extend the analytical scope of applied resilience ecology, by exploring the internal diversity of resilience in Ireland throughout this period. Through a cluster analysis of aggregate Irish data from the mid-nineteenth century, it attempts to quantify the determinants of regional-level risk exposure by grouping regions into distinct social-ecological regimes according to demography, geography, and social structure within Ireland's 32 counties. This alternative methodology seeks to combine political-economic indicators relevant to the entitlements approach, along with other indicators of social-ecological structure which reveal the channels through which lower-level regional units may become exposed to heightened ecological risk. In this way, an analysis of the macro-level political economy of food security may be combined with a more nuanced model of social-ecological structure, in order to augment the shortcomings of a strictly political-economic, or food supply model alone.

\section{The macro-context of nineteenth century Ireland}

Existing accounts of the social, agrarian, and ecological structure of Ireland throughout the Great Famine have often resorted to macro-models and typologies, which attempt to impose conceptual uniformity on the Island as a whole. Kevin Whelan's four-fold typology of eighteenth century 'regional archetypes' centered on dominant productive activities, is prominent amongst these (Ó’ Gráda, 1994: 35; Whelan, 1995, 2000). Whelan’s model identifies a pastoral archetype running from Leinster in the east, to inner Connaught in the west, driven by export price fluctuations; a tillage archetype of mixed farming extending across the south-eastern Anglo-Norman coastlands from Cork to Wexford, and northwards from Wicklow to Dundalk; and a proto-industrialisation archetype, spurred by favourable technology, infrastructure, and competitive innovation, centred on key northern production zones of the Ulster linen trade (Whelan, 2000). Whelan's fourth archetype of small farming, concentrated in a western crescent running from Cork to North Donegal, is of greatest interest in light of its problematic influence on Irish historical geography throughout the twentieth century. The unique ecology of this marginal 'peasant fringe' has long featured as a recurrent theme in both academic and popular discourse (MacNeill, 1921). Historically, this zone of 
settlement has been associated with poor quality marginal lands, high rates of poverty, and the extensive presence of the rundale system (Evans, 1957).

Rundale was a system of communal land management practiced extensively throughout the west of Ireland during the eighteenth and nineteenth century, where farms were held in partnership, and individual families were allocated shares, subject to periodic redistribution by a deputed headman, or village council (Bell and Watson, 2006; McCourt, 1955a; Slater, 1988). The lands of the infield, adjacent to the village buildings or 'clachán' were kept under continuous tillage, whilst livestock were herded for summer grazing on surrounding lands known as the 'outfield' (O’ Sullivan and Downey, 2008). The balance of tillage and livestock offered by this infield-outfield rotation, enabled a system of mixed farming to thrive amongst individuals with otherwise limited resources (Uhlig, 1961; McCourt, 1955b). In the winter, livestock were permitted free reign over the infield lands to graze crop stubble, providing a crucial source of fertiliser for the subsequent growing season. The pooling of labour within rundale also allowed for extensive land reclamation, enabling the system to sustain rapid demographic growth during the eighteenth century (Slater and Flaherty, 2009). An erroneous over-generalisation of this western small farm archetype to the island as a whole, thus formed the basis of a monolithic 'peasant subsistence' model of pre-famine Irish agriculture, which glossed over the internal complexities of settlement distribution, social stratification, and economic activity (Doherty, 2000).

There is much evidence to warrant a closer inspection of the characteristics of this Western small farm archetype. According to the work of Desmond McCourt (1971), the existence of a peripheral small farm, or distinctively western archetype is substantiated by first edition ordnance survey maps of the 1840's, which reveal extensive clachán settlement - the characteristic village clusters of rundale - concentrated within the areas bounded by Whelan's small farm zone (see figure 1 below for a tabulation of common holding rates within counties). For County Mayo, Desmond McCabe (1991) estimated up to 831,000 acres, or $63 \%$ of the total area of County Mayo, was held in rundale in the 1840's. Classic pronouncements on Ireland's unique demographic regime, such as those of K.H. Connell (1950b, 1962), have also identified the critical roles of wasteland reclamation, and the ability of the potato both to prosper in poorer quality soils, and to yield a diet of sufficient calorific adequacy on small acreages, as key factors facilitating early marriage, high fertility, and high population density under rundale. 




Figure 1. Lands held in common or joint tenancy (rundale) (Devon Commission 1845)

The rundale system was thus especially ecologically precarious; it suffered from overpopulation and monoculture dependence, whilst being simultaneously tied into a rent relationship under British colonialism, as was the case with all Irish tenant farmers at this time (Slater and McDonough, 2005). This relationship required the continuous sale of agricultural surplus in order to meet rental obligations to local landlords. As agricultural produce was sold beyond the boundaries of these settlements to be consumed in urban centres far from their sites of production, they suffered declines in fertility through loss of repatriated nutrients, and came to subsist on a narrower range of crops as their grains were increasingly consigned to the market (Flaherty, 2013; Hooper, 1922). There is little doubt that this western crescent was subject to the worst effects of the famine between the years 1845 and 1852, as Kinealys' poor-law union level analysis of variability in the uptake of soup rations throughout the famine years has identified a concentration of high distress in the western counties of Galway, Mayo, Clare, Kerry and Limerick (2006: 369). 
Tabulation and mapping of agricultural census data of 1851 completed by the National Centre for Geocomputation (2010), further underscores the presence and continuities of such regional distinctions. As may be observed in figures 2.1-2.4, profound regional distinctions are evident in crop distribution patterns. Production of potato (figure 2.1) follows a western crescent with some southern and north-eastern pockets, whilst that of wheat (figure 2.2) is centred along an Anglo-Norman tract extending from the south-west to south east coasts, whilst flax cultivation (figure 2.3) is centered on the protoindustrial spinning and weaving districts of the north. Valuation (figure 2.4) displays a distinct westerly trend, with concentrically decreasing levels from east-west. Although a number of profound correlations are evident, most notably a concentration of potato cultivation and lower land valuation across the western fringe - in turn corresponding to the distribution of rundale as noted in figure 1 - some reservations are warranted.

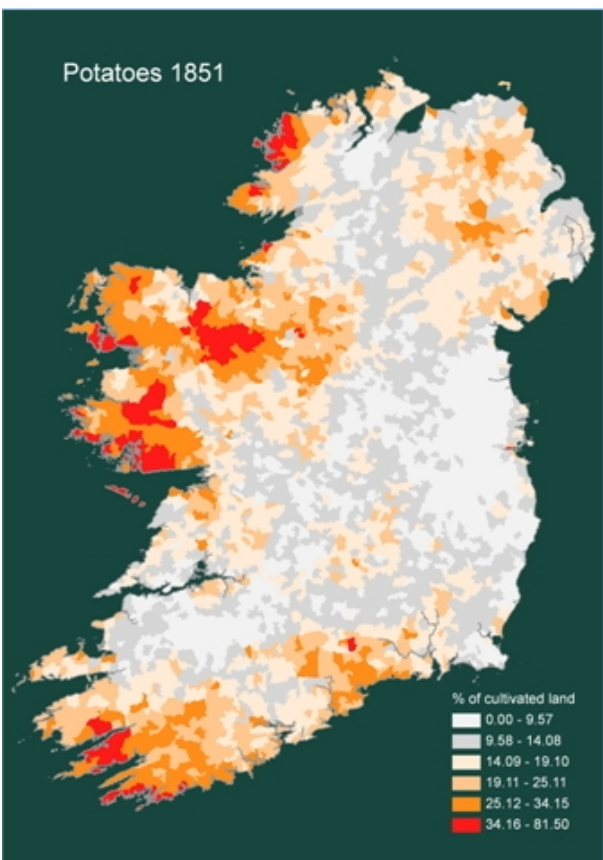

Figure 2.1. Potato as \% cultivated land (National Centre for Geocomputation, 2010)

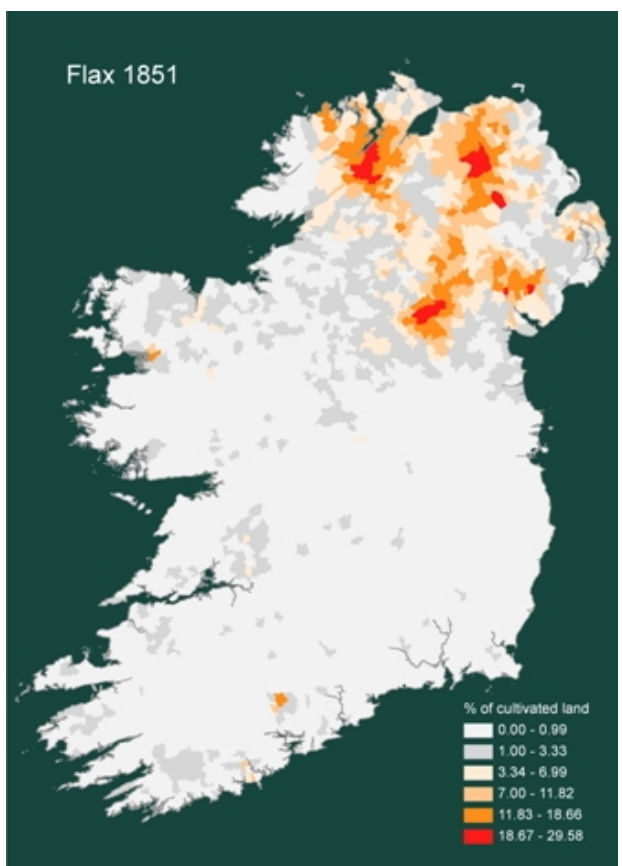

Figure 2.3. Flax as \% cultivated land (National Centre for Geocomputation, 2010) 


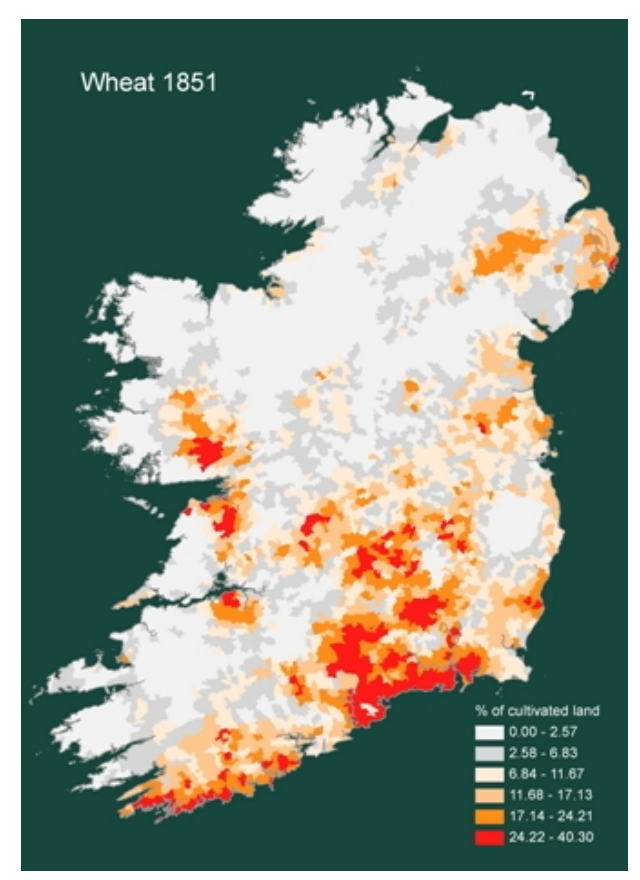

Figure 2.2. Wheat as \% cultivated land (National Centre for Geocomputation, 2010)

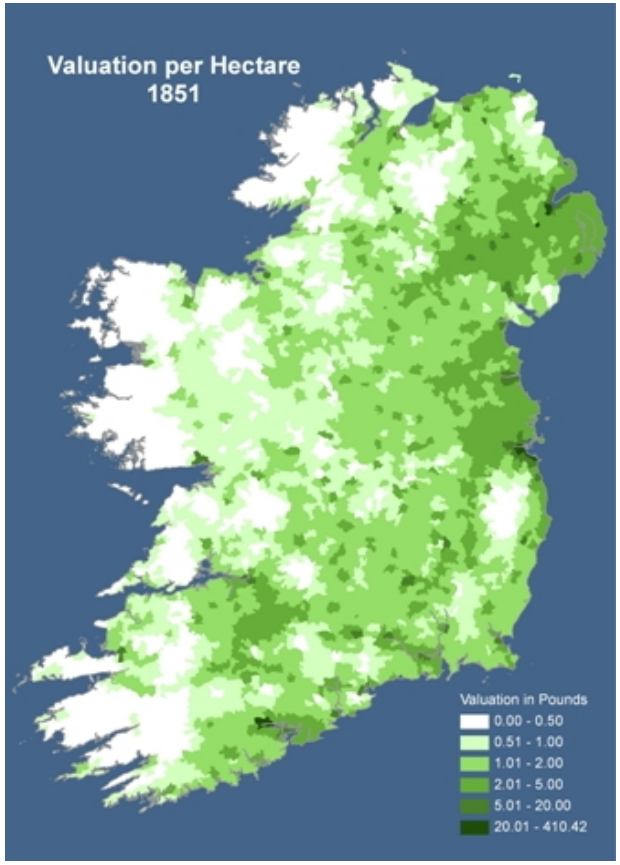

Figure 2.4. Valuation per hectare (National Centre for Geocomputation, 2010)

On the extent of domestic industry for example, Almquist (1977) and Gray (2005) have pointed out that spatial typologies alone are not representative of its true significance throughout this period, as large proportions of rural households along the western Atlantic seaboard engaged in small-scale spinning as a key source of supplementary income (Gray notes over 50\% of all occupied women in Donegal, Galway and Mayo were spinners, 2005: 52). Furthermore, patterns of high land fragmentation and early female nuptiality thought characteristic of the 'small farm zone' of the west of Ireland, prevailed across much of Ireland throughout the early nineteenth century, resulting in $45 \%$ of all enumerated holdings across Ireland falling below five acres by 1841 (Connell, 1950b: 284). This presents both a conceptual and typological problem; given that similar social processes such as protoindustrialisation and land subdivision operated across regional boundaries, univariate spatial typologies alone are arguably incapable of fully revealing the complex dynamics underpinning the formation of regional inequalities in poverty, and ecological risk exposure.

In order to make sense of famine-era variations in resilience and risk exposure, given that reliance on geographical patterning only takes us so far, what is instead required is a typological approach which permits closer examination of the presence of regional distinctions and consistencies at a greater level of abstraction, using variables which move beyond productive activity alone. Resilience ecology suggests working from local contexts, in order to identify specific sets of conditions which may generate uneven patterns of risk exposure. Such an approach requires working with data in a manner different from cross sectional modelling; what we are seeking to uncover is not the additive effect of variables across complete sets of data, but rather the ways in which variables 'group together' in different ways across cases, giving rise to differing levels of resilience. Cluster analysis therefore offers a way to develop a comparative typology capable of addressing this question of multilevel systemic complexity. 


\section{Data and methods}

The following sections present the results of an exploratory $k$-means cluster analysis, conducted with the intention of extracting a latent typology of cases from a set of countylevel variables $(\mathrm{N}=32)$ measuring a range of social, geographic, and demographic attributes of mid nineteenth-century Ireland. These county units incorporate all of the land mass of Ireland at this time. In context of the preceding discussions, and on the basis of prior empirical research, particularly that of Eric Almquist (1977), who has subjected many of the following variables to regression modelling with productive results, the following variables were selected (see table 1). These variables represent a parsimonious range of attributes relevant to the social-ecological profile of Ireland at this time, through which regimes of ecological risk may be discerned.

The inclusion of demographic variables in the form of land-labour ratio and females 26-35 married/widowed is substantiated by existing literature on Ireland as discussed above, and within broader works in human ecology (see table 1 for variable descriptions, and theoretical justifications). Age at marriage is largely a function of local conditions such as access to land for new settlement, inheritance patterns, family structures, and local cultural norms. This variable allows us to distinguish areas of later and earlier marriage trends, where union may be delayed owing to difficulties in securing inheritance, in the absence of subdivision or land reclamation. Therefore, areas with higher nuptiality rates, extensive subdivision, and limited outmigration should record higher percentages on this variable. Such population-specific variables often feature as predictors of stress in models of resource consumption (Axinn and Ghimire 2011).

The inclusion of variables beyond these 'Malthusian' parameters alone is justified in the context of this study, as a counterpoint to simple population determinism; hence the inclusion of land held in common or joint tenancy as an index of the presence of particular institutional modes of land governance (the communal rundale system as discussed above). The role of wasteland as a determinant of settlement expansion is well established in existing work, and many have drawn attention to the inherent tendencies of collective leasing regimes such as rundale, particularly as they permit reclamation, and consequently, accommodation of new settlement members (Connell 1950b; Currie 1986; McCourt 1955a, 1971; Slater and Flaherty 2009). Elinor Ostrom's work (1990) has also shown how systems of common pool resource governance are ideally suited to intense resource exploitation, where large territories are required to make production viable, and where large groups are needed to perform the common labour necessary to bring marginal lands under cultivation. These reclamation activities were particularly prevalent across rundale-dense areas. Summary statistics, correlations, and a scatterplot matrix are provided below in tables $2 \& 3$, and figure 3 . 
Table 1. Description of input variables

\begin{tabular}{|c|c|c|c|}
\hline Variable & Unit & Source & Theoretical/empirical justification \\
\hline Land-labour ratio & $\begin{array}{l}\text { Statute acres } \\
\text { per individual }\end{array}$ & $\begin{array}{l}\text { Census of Ireland, } \\
\qquad 1841\end{array}$ & $\begin{array}{l}\text { Hypothesised by Chayanov as key determinant of household labour } \\
\text { strategies. Elevated/diminished ratios are associated with probability of } \\
\text { uptake in subsidiary domestic industry / labour intensive crop cultivation } \\
\text { (O’ Neill 1984) }\end{array}$ \\
\hline Poor law valuation & $\begin{array}{l}£ \text { (pounds) per } \\
\text { individual }\end{array}$ & Almquist (1977) & $\begin{array}{l}\text { Reliable index of poverty - lower valuations are associated with lower } \\
\text { potential land productivity }\end{array}$ \\
\hline $\begin{array}{l}\text { Females } 26-35 \text { married or } \\
\text { widowed }\end{array}$ & $\%$ all females & $\begin{array}{l}\text { Vaughan and } \\
\text { Fitzpatrick (1978) }\end{array}$ & $\begin{array}{l}\text { Cited as key independent variable in land-use outcome explanation. Often- } \\
\text { hypothesised component of pre-famine Irish demographic expansion } \\
\text { (Connell 1950a), closely related to subdivision, and viability of potato }\end{array}$ \\
\hline Holdings $1-5$ acres & $\begin{array}{l}\% \text { of all } \\
\text { holdings }\end{array}$ & Almquist (1977) & $\begin{array}{l}\text { Rundale systems are characterised by fragmentation of holdings through } \\
\text { subdivision }\end{array}$ \\
\hline $\begin{array}{l}\text { Waste (course pasture) below } \\
\text { 800ft above sea level }\end{array}$ & $\begin{array}{l}\% \text { of all } \\
\text { county } \\
\text { wasteland }\end{array}$ & $\begin{array}{l}\text { Devon Commission } \\
\text { (1845) }\end{array}$ & $\begin{array}{l}\text { Wasteland / course pasture encroachment cited as characteristic of rapidly } \\
\text { expanding rundale settlements. Wasteland availability conducive to } \\
\text { resilience of communal systems through spatial expansion }\end{array}$ \\
\hline $\begin{array}{l}\text { Land held in common or joint } \\
\text { tenancy }\end{array}$ & $\begin{array}{c}\% \text { of all } \\
\text { county land }\end{array}$ & $\begin{array}{l}\text { Devon Commission } \\
\text { (1845) }\end{array}$ & Indicator of potential presence of the rundale system of communal tenancy \\
\hline
\end{tabular}


Table 2. Input variable summary statistics $(\mathrm{N}=32)$

\begin{tabular}{|c|c|c|c|c|c|}
\hline Variable & Unit & Mean & SD & Min & Max \\
\hline Land-labour ratio & $\begin{array}{l}\text { Statute acres per } \\
\text { individual }\end{array}$ & 2.68 & 0.81 & 0.61 & 4.04 \\
\hline Poor law valuation & $\begin{array}{l}£ \text { (pounds) per } \\
\text { individual }\end{array}$ & 1.56 & 0.58 & 0.66 & 3.03 \\
\hline $\begin{array}{l}\text { Females } 26-35 \text { married } \\
\text { or widowed }\end{array}$ & $\%$ all females & 70.35 & 6.03 & 59.49 & 81.85 \\
\hline Holdings $1-5$ acres & $\begin{array}{l}\% \text { of all } \\
\text { holdings }\end{array}$ & 42.33 & 11.12 & 27.9 & 72.6 \\
\hline $\begin{array}{l}\text { Waste (course pasture) } \\
\text { below } 800 \mathrm{ft} \text { above sea } \\
\text { level }\end{array}$ & $\begin{array}{l}\% \text { of all county } \\
\text { wasteland }\end{array}$ & 57.9 & 26.00 & 0 & 98.46 \\
\hline $\begin{array}{l}\text { Land held in common } \\
\text { or joint tenancy (logged } \\
\text { for cluster model and } \\
\text { correlations) }\end{array}$ & $\%$ of all land & 8.91 & 12.42 & 0 & 58.7 \\
\hline
\end{tabular}

Table 3. Correlation matrix $(\mathrm{N}=32)$

\begin{tabular}{|c|c|c|c|c|c|c|}
\hline & Land-Labour & Poor law & Married & 1-5 acre & Waste & Common \\
\hline Land-labour & 1.000 & & & & & \\
\hline Poor law & -0.1308 & 1.000 & & & & \\
\hline Married & 0.1466 & $-0.6568 * * *$ & 1.000 & & & \\
\hline 1-5 acre & -0.0346 & $-0.5368 * *$ & $0.6351 * * *$ & 1.000 & & \\
\hline Waste & $0.5134^{* *}$ & -0.3276 & $0.4500^{* *}$ & 0.3276 & 1.000 & \\
\hline Common & 0.1989 & $-0.4648 * *$ & $0.4393 *$ & 0.0842 & 0.1038 & 1.000 \\
\hline
\end{tabular}

${ }^{*} p<0.05, * * p<0.01, * * * p<0.001$ 


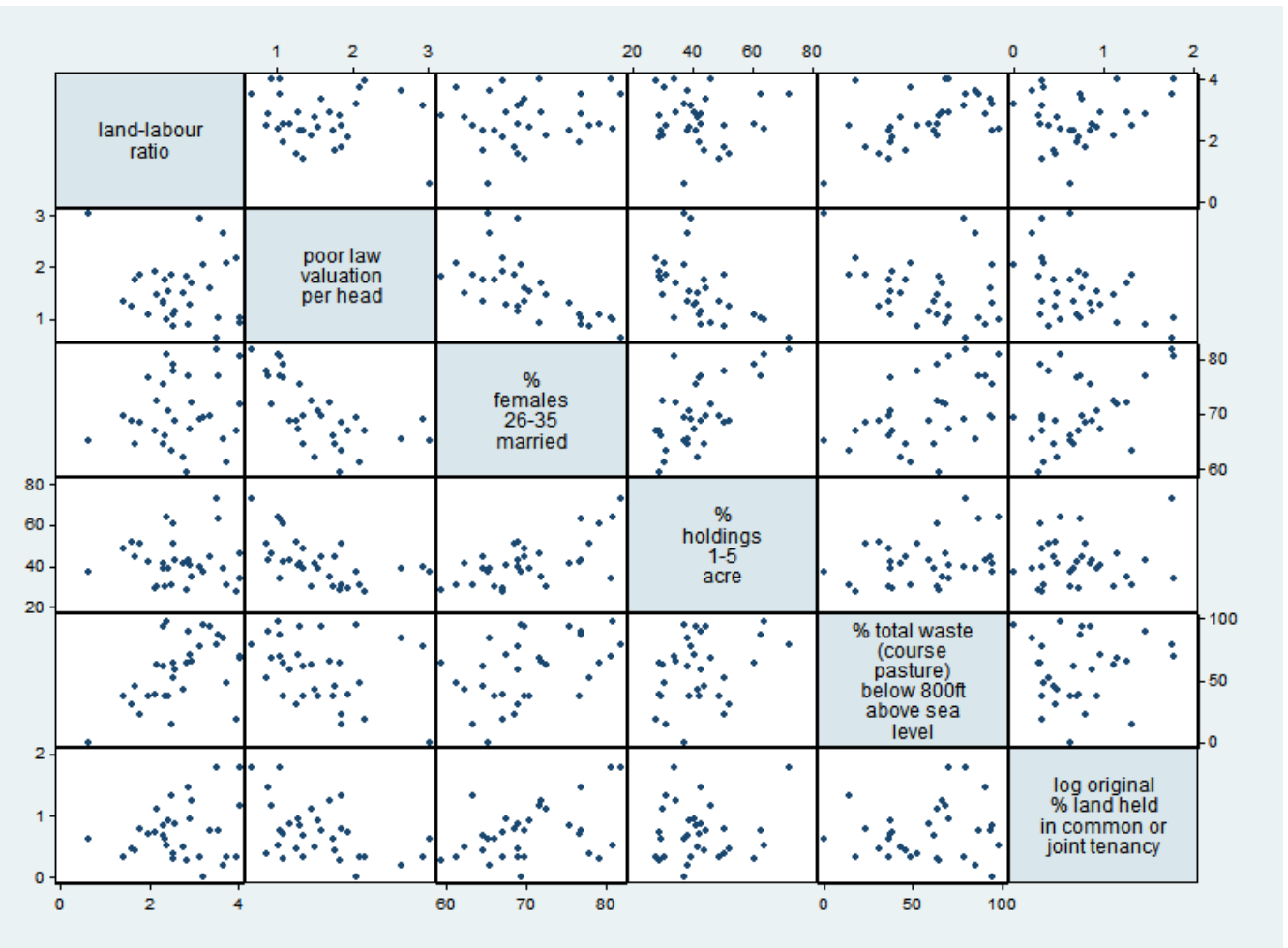

Figure 3. Input variable scatterplot matrix

As may be observed in the above tables and figures, and as previously detailed by Almquist's cross-sectional models (1977), the chosen input variables exhibit suitably broad ranges (table 2, min \& max). Furthermore, a number of significant correlations are evident within table 3 and figure 3. Consistent with existing theory, the key demographic variable of females 26-35 married demonstrates strong, significant correlations with others including holdings 1-5 acres $(\mathrm{r}=0.6351, \mathrm{p} \leq 0.05)$, waste $(\mathrm{r}=0.45, \mathrm{p} \leq 0.05)$ and common $(\mathrm{r}=0.4393, \mathrm{p} \leq 0.05)$. Thus we observe strong positive associations between the demographic regime of high early female nuptiality, classical predictors of population growth (availability of wasteland), and a number of consequent effects of demographic expansion, such as fragmentation of holdings, and the presence of common holding. Of note also are strong, negative associations between land valuation (poor law valuation), females 26-35 married ( $\mathrm{r}=-0.6568, \mathrm{p} \leq 0.05$ ), holdings 1-5 acres $(\mathrm{r}=-0.5368, \mathrm{p} \leq 0.05)$ and land held in common $(\mathrm{r}=-0.4648, \mathrm{p} \leq 0.05)$. Such associations point toward a diminished probability of early marriage, land fragmentation and common holding within more affluent districts.

As stated above, the purpose of exploratory cluster analysis is to extract latent typologies of cases. For $k$-means optimization techniques as utilised below, $k$ denotes the number of groups required by the clustering procedure, and is a user-defined input parameter (unlike hierarchical procedures which progressively match cases on the basis of similarity/distance measures). $K$ means clustering adopts trace (W) minimization as its optimization criteria (see Everitt et al 2011: 126). Although a number of formal procedures exist for the estimation of potential group numbers for optimisation clustering methods, such as the Calinski and Harabasz pseudo Fstatistic (Rabe-Hesketh and Everitt 2004: 276), and the Duda and Hart index (Everitt et al 2011: 127), Landau and Everitt (2004) suggest that many of these techniques are inherently adhoc. Mardia, Kent and Bibby's rule of thumb $\left[g \sim(\mathrm{n} / 2)^{.5}\right]$, for example, yields a preliminary value of 4 , where $n$ is the number of counties - in this case, 32 (1979: 365). On the basis of 
existing theory and research, and in light of the small available sample size, an input constraint of four groups was specified. This estimated value of $k$ agrees with previous classifications of Ireland, which have tended to emphasise four distinct socio-economic zones (Ó’ Gráda 1994, Whelan 2000, National Centre for Geocomputation 2010).

All variables were z-score standardised (to mean 0 , standard deviation 1 ) prior to application of the clustering algorithm, consistent with Everitt et al's recommendations, given that optimization methods are inherently scale dependent (Everitt et al 2011: 115). A log transformation was also applied to the variable common prior to clustering, in order to correct a profound positive skew, with the addition of a constant of 1 , due to the presence of ' 0 ' values in the original dataset. Correlations from table 3, figure 3, and the boxplot of figure 5 report values for the transformed variable, whilst other output (tables 2 and 4) reports values from the untransformed variable for ease of interpretation.

\section{Results and discussion}

The benefits of employing a $k$-means method in the context of this research, are that such techniques '...seek to minimize the variability within clusters and maximise variability between clusters' (Landau and Everitt 2004: 312), yielding a set of groups optimally distinct from each other, yet retaining a significant degree of internal homogeneity (Byrne 1998). This process is theoretically consistent with the concept of regimes as informed by resilience ecology, whereby each cluster group may be interpreted as a distinct, internally consistent socialecological regime. Complete output generated from the clustering procedure is provided as an appendix, although this output is less intuitively interpretable owing to necessary standardisations employed prior to running the clustering algorithm. The reader may discern cluster centroids more intuitively through the following tables (3 and 4), which tabulate final cluster solution group members (table 3 ), and input variable summary statistics according to derived cluster group membership (table 4).

Table 3. Cluster solution group members

\begin{tabular}{cccc}
\hline Group 1 & Group 2 & Group 3 & Group 4 \\
\hline Antrim & Armagh & Carlow & Dore \\
Down & Cavan & Kildare & Galway \\
Dublin & Cork & Meath & Kerry \\
Kilkenny & Fermanagh & Queen's & Mayo \\
Louth & King's & Westmeath & Wexford \\
Tipperary & Leitrim & Wicklow & \\
Waterford & Limerick & & \\
& Londonderry & & \\
& Longford & & \\
& Monaghan & & \\
& Roscommon & & \\
\end{tabular}




\begin{tabular}{|c|c|c|c|c|c|c|c|c|c|}
\hline \multirow[t]{2}{*}{ Variable } & \multirow[t]{2}{*}{ Unit } & \multicolumn{2}{|l|}{ Group 1} & \multicolumn{2}{|l|}{ Group 2} & \multicolumn{2}{|l|}{ Group 3} & \multicolumn{2}{|c|}{ Group 4} \\
\hline & & Mean & SD & Mean & SD & Mean & SD & Mean & SD \\
\hline Land-labour ratio & $\begin{array}{l}\text { Acreage per head of } \\
\text { population }\end{array}$ & 1.93 & 0.67 & 2.40 & 0.54 & 3.33 & 0.47 & 3.60 & 0.47 \\
\hline Poor law valuation & $£$ (pounds) per head & 1.96 & 0.49 & 1.27 & 0.23 & 2.17 & 0.48 & 0.91 & 0.15 \\
\hline Females 26-35 married & $\%$ all females & 66.47 & 2.44 & 72.61 & 4.94 & 64.84 & 3.89 & 77.62 & 3.95 \\
\hline Holdings 1-5 acres & $\%$ all holdings & 37.31 & 8.14 & 45.43 & 9.69 & 34.90 & 5.62 & 51.72 & 15.78 \\
\hline $\begin{array}{l}\text { Waste (course pasture) } \\
\text { below } 800 \mathrm{ft} \text { above sea } \\
\text { level }\end{array}$ & $\%$ total county waste & 28.13 & 16.34 & 63.78 & 21.81 & 61.70 & 26.74 & 78.99 & 9.67 \\
\hline $\begin{array}{l}\text { Land held in common or } \\
\text { joint tenancy }\end{array}$ & $\%$ all land & 6.44 & 6.08 & 5.39 & 21.81 & 1 & 0.64 & 32.66 & 24.99 \\
\hline
\end{tabular}


On the basis of these results, a number of distinct social-ecological regimes may be discerned; this typology performs well in isolating the characteristics of areas prone to ecological stress, by identifying conditions within regions which (as will be examined below), exacerbated the experience of distress during the peak famine months. In light of the summary statistics presented in table 4, a distinct regime may be observed, described by the territories of Group 4 (Clare, Donegal, Galway, Kerry and Mayo); the consistency of this group is defined by its high land-labour ratio (3.6), low poor law valuation (£0.91), high proportions of females 26-35 married (77.62\%), high fragmentation of holdings 1-5 acres (51.72\% of all holdings), high availability of wasteland (78.99\%), and greater prevalence of common landholding (32.66\%). This may be contrasted with the regime described by Group 1, characterised by significantly higher valuation (£1.96), lower fragmentation of holdings 1-5 acres (37.31\%), limited wasteland (28.13\%), and comparative absence of common landholding (6.44\%). The magnitude of these between-group differences may be observed by examining boxplots generated by cluster group membership for variables female 26-35 married (figure 4) and land held in common or joint tenancy (figure 5).



Figure 4. Boxplot (\% females 26-35 married or widowed) by cluster group membership 


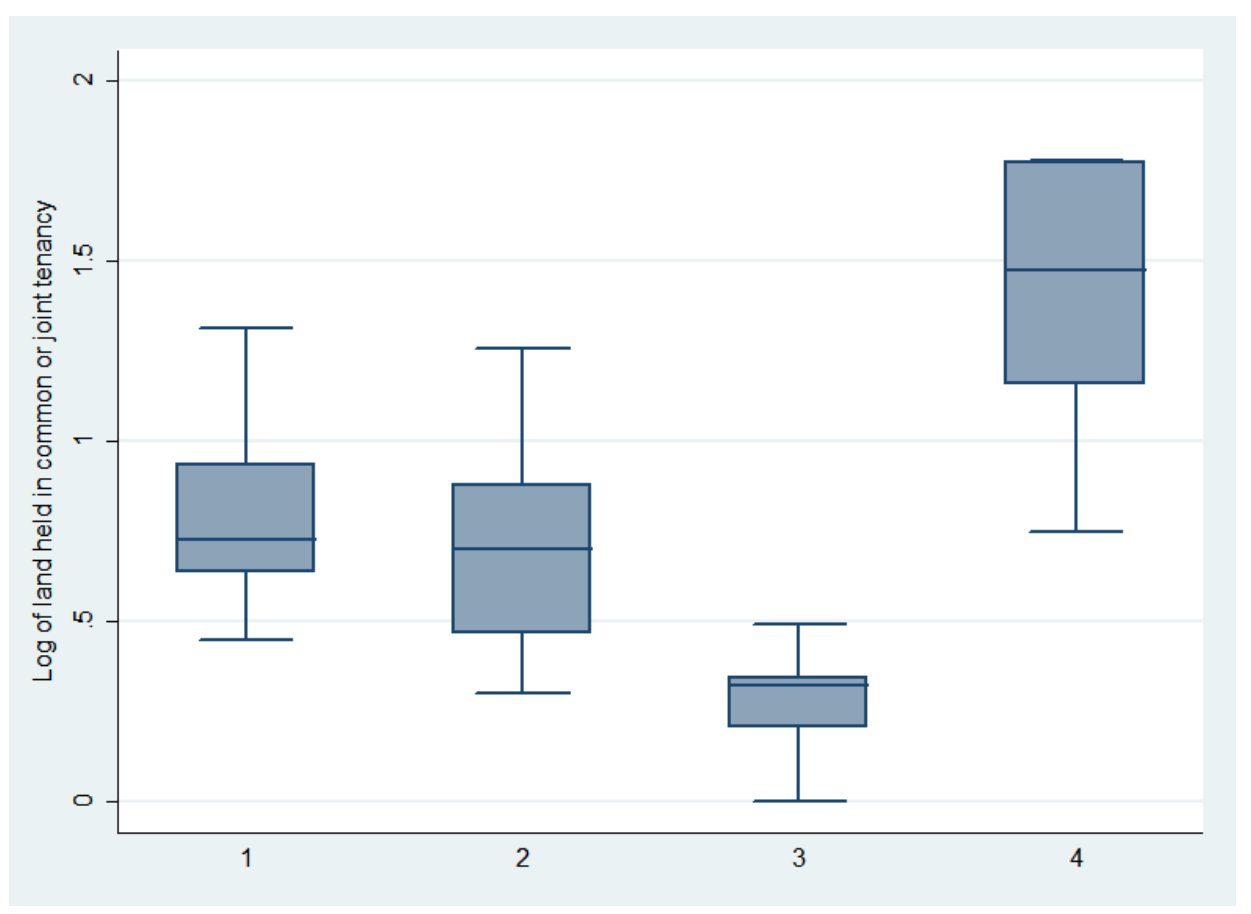

\section{Figure 5. Boxplot (log \% land held in common or joint tenancy) by cluster group membership}

A further advantage of this approach is that it allows us to move beyond stability-based metrics such as aggregate population growth, which are incapable of adequately grasping potential heterogeneity in sub-system variants; '...stability concepts can, with the exception of 'persistence', not be applied to entire systems but only to specific state variables characterizing these systems' (Grimm and Calabrese 2011: 5). Adopting a definition of resilience centered on the capacity of a system to '...retain essentially the same function, structure, identity, and feedbacks' (Walker 2004 cited in Grimm and Calabrese 2011: 8), it is clear how the regional characteristics described by the above typology conferred varying degrees of risk exposure. In the case of group four, the comparatively poorer quality of land, and its lower potential productivity (poor law valuation), coupled with high rates of fragmentation (Holdings 1-5 acres), led to greater stress on the means of production as communities were forced to subsist on plots of diminishing size. This condition was assisted both by the presence of available wasteland for colonisation (Waste), spurred by a demographic regime of high early nuptiality (Females 26-35 married). These critical dynamics are often cited in the literature on Ireland as key pre-famine stressors, although their varying prevalence across Ireland at this time has not been adequately substantiated (Connell 1950a, 1950c).

In the rundale-dense counties of group four, the capacities of common holding regimes to adapt to conditions of ecological marginality has often been emphasised (Whelan 1995, 1999). Under pre-famine landlordism, the rundale system was ideally suited for rent-based profit maximisation, given its tendencies toward exponential growth. With abundant wasteland to accommodate new members, and the prolific potato crop which yielded sufficient output to feed families on small acreages, landlords permitted subdivision on their estates as a means of maximising rent returns throughout the buoyant grain economy of the Napoleonic wars (Slater and McDonough 2005). As the post-war grain economy contracted, and prices of livestock and wool began to increase, the imperatives of landlordism quickly shifted toward consolidation: the clearing of estates, enclosing of commons, and letting of lands to large graziers. As a result, 
the regions of group four experienced particular resilience loss, as their capacity to adapt to change became rapidly diminished in the pre-famine era (Slater and Flaherty 2009). As eviction, clearance, and excess mortality took hold into the late 1840's, the ability of settlements within this group to maintain their structure and identity was critically compromised.

Clearly this narrative risks glossing over local heterogeneity and caution must be exercised in mapping any such model onto particular cases. When comparing group four with group three, the qualitative differences amongst regimes are most clearly underscored. Many of the counties of group three occupy Whelan's classic 'tillage zone', where grain productivity was typically at its highest. Such areas benefitted from productivity upscaling under land consolidation, and from wartime grain price upsurges, as reflected in this cluster's high valuation (poor law valuation), and low levels of fragmentation (Holdings 1-5 acres). Common holding (Land held in common) was all but absent, and nuptiality was lower (Females 26-35 married), leaving this cluster beyond the boundaries of the classic demo-economic model of expanded fertility (Clarkson 1981; Connell 1950a; Gray 2005), typically brought to bear on the island as whole.

\section{Resilience and distress: the uneven impact of famine}

The explanatory power of these qualitative regime differences is further illustrated by a decomposition of distress estimates across cluster group membership (figure 6). The below data on ration uptake are drawn from six successive reports of May $8^{\text {th }}$, June $5^{\text {th }}$, July $3^{\text {rd }}$, July $31^{\text {st }}$, August $28^{\text {th }}$ and September $11^{\text {th }} 1847$, and the largest number of rations issued on a single date across all reporting periods was selected for inclusion. This current measure differs slightly from that of Kinealy (2006), as it is first calculated as the rate of rations issued per head of population before standardization (again, to mean 0, standard deviation 1). Figure 6 (below) shows how group four fared worst in terms of the uptake of gratuitous relief rations during the critical summer months of 1847, when the impact of famine was reaching its peak.

A one-way ANOVA with post-hoc group comparison quantifies the magnitude of these between-group differences more precisely, and table 5 (below) shows how membership of group four was associated with significantly greater ration uptake. The extent of ration uptake within group four contrasts markedly with that of groups two and three, as may also be observed in figure 6. Although it is impossible to include additional covariates and controls owing to the small sample size of this dataset, the difference recorded for group four, coupled with its significance in the model, suggests that it stands apart as a regime of particular hardship. 


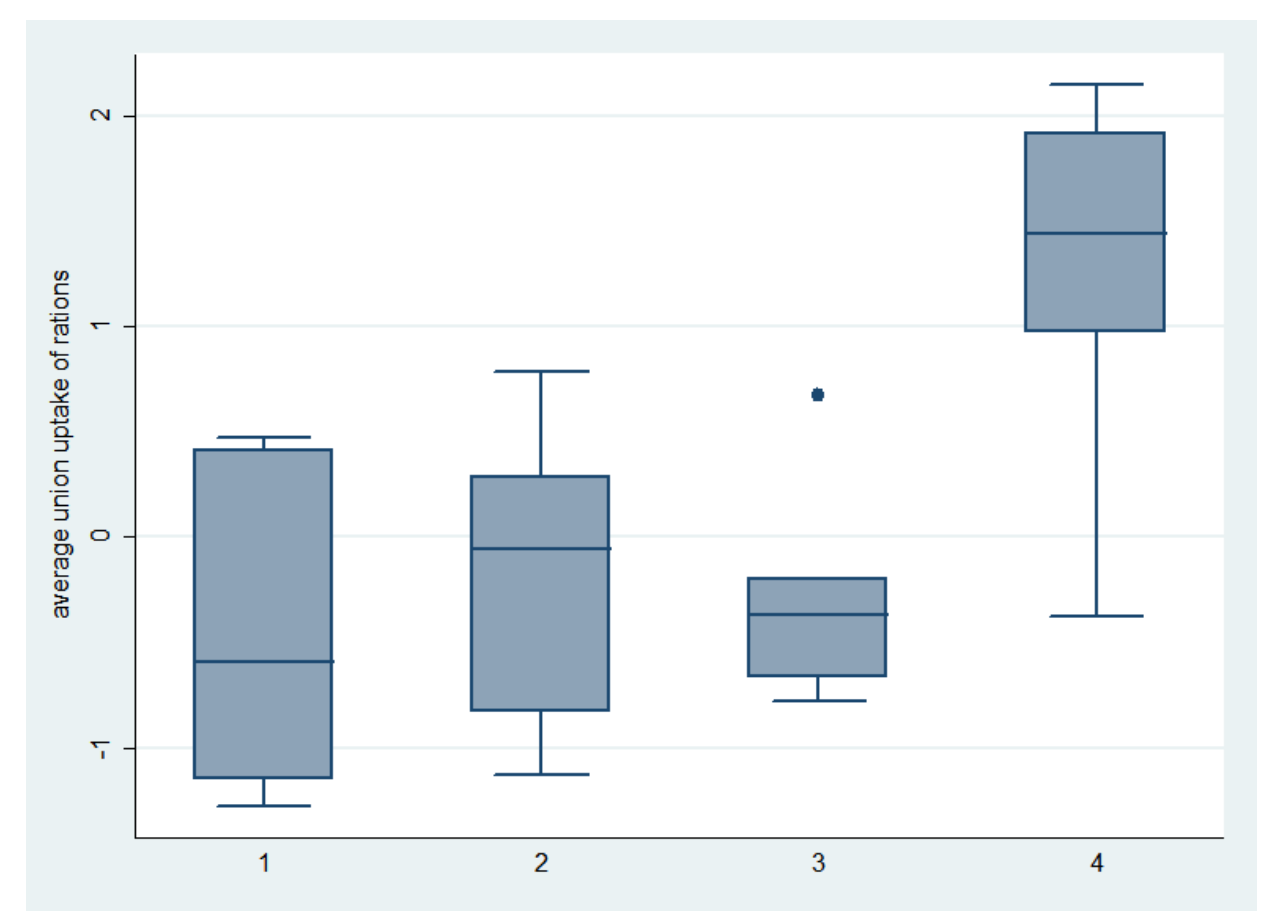

Figure 6. Uptake of relief rations by cluster group membership

Table 5. One-way ANOVA with post-hoc group comparisons (Dunnett)

\begin{tabular}{lcc}
\hline & Mean difference & Standard error \\
\hline Group 1 (reference) & - & - \\
Group 2 & -.287 & .331 \\
Group 3 & -.023 & .302 \\
Group 4 & $1.14^{* * *}$ & .331 \\
\hline F & & \\
$\mathrm{N}$ & & $3.305^{* * *}$ \\
\hline
\end{tabular}

\section{$* * * p<0.001$}

Data on ration uptake sourced from Second Report of the Relief Commissioners, constituted under the act $10^{\text {th }}$ Vic., cap. 7. 1847 [819] xvii, pp24-26; Third Report of the Relief Commissioners, constituted under the act 10 ${ }^{\text {th }}$ Vic., cap. 7. 1847 [836] xvii, pp30-31; Fourth Report of the Relief Commissioners, constituted under the act 10 ${ }^{\text {th }}$ Vic., cap. 7. 1847 [859] xvii, pp6-7; Fifth, Sixth and Seventh Reports of the Relief Commissioners, constituted under the Act $10^{\text {th }}$ Vic., cap. 7. 1847-48 [876] xxix, pp7-8; 8-9; 8-9

The subjective experience of distress between groups was also somewhat different. Writing on the county of Mayo (group four) in the winter of 1847, Poor Law Union inspector Richard Hamilton observed; ' ...I visited the village a month ago, and found the greatest destitution existing in it; but on going there again the day before, I was not a little astonished to find 
nothing but the walls of the houses remaining, the inhabitants being scattered through the country seeking shelter where they could best find it' (Yager 1996: 30). Many landlords took advantage of famine conditions to enact estate-wide clearances of smallholders and rundale tenants, and estimates of the extent of famine-era evictions stand at between 200,000 and 250,000 individuals (Orser 2006b: 180). According to Vaughan, '.... around 37,286 evictions may have occurred between 1846 and 1849 alone, with somewhere around 16,400 houses being levelled' (ibid).

The comparative resilience of group two was doubtless augmented by the presence of protoindustrialization in the Northern counties of Fermanagh, Cavan, Armagh, and Londonderry, and their close integration with the core 'linen triangle' of Dungannon - Belfast - Armagh (see the distribution of flax in figure 2.3). In such cases, buoyant linen markets offered a subsidiary source of income which imbued such regions with an inherent market-derived flexibility (Gray 2005). This could also have an opposing effect however. Rev. Nixon of North West Donegal (group four), upon assuming title to the Copeland estate in 1844, promptly annexed extensive tracts of mountain land in order to graze a prolific breed of sheep in response to rising wool prices, disrupting long-held grazing rights of the tenantry who were accustomed to grazing their livestock on the mountain commonage, as an essential component of their seasonal rotation (Mac Aoidh 1990).

Crucially, the differing between-group nature of the 'indirect entitlement' of subsidiary industry is more intelligible in context of the conditions revealed in the above cluster analysis. In the case of group two, elevations in early nuptiality were absorbed by the division of household labour in domestic spinning, and the importance of these subsidiary domestic industries as a means of absorbing excess labour has been well substantiated by existing scholarship (Almquist 1977; Gray 2005). Thus in group two, elevated nuptiality and land fragmentation were offset by the proximity of some counties to buoyant linen markets in the North. In other groups, high nuptiality, combined with high fragmentation, and the comparatively smaller scale of domestic spinning, meant that such areas were materially poorer due to their sustained dependence on direct subsistence, and other sources of farm-related income.

Comparative disadvantage was also compounded within group four, due to the absence of capital investment in agriculture, unlike in the northern counties where the provisions of 'Ulster custom' ensured that tenants retained the right to uninterrupted sale of their lease, allowing them to benefit from fixed agricultural improvements (Dowling 1999). Similar provisions were not in place beyond the north. Due to the communal nature of production under rundale, and the balance of legal property rights in favor of agent and landlord throughout all regions, investments in permanent improvements made little economic sense to the southern tenantry, who stood to lose the value of their labour should their lands be sold, or their plots redistributed. As a result, the counties of group four suffered from multiple constraints, owing to the underdevelopment of agricultural capital and technology, high settlement density, and the insecurity of seasonal productivity on marginal lands. By the time blight arrived in 1845, the conditions of crisis were firmly entrenched; it required merely a small change in ecological fortune to destabilize the system to the point of collapse (see also Fisk and Kerhevre 2006; Kinzig et al 2006).

\section{Conclusion: theoretical and methodological implications}


The preceding exercise has captured substantial internal diversities not typically revealed through the use of aggregate models, and the regimes identified above further underscore the problematic nature of Malthusian models of food security. Although nationwide demographic expansion doubtless fed into the precariousness of Irish society in the pre-famine era, this was mediated profoundly through local variations in social-ecological resilience, as captured by the above typology. Such diversity renders any account of food security based on national-level causes problematic, insofar as the ability of regions to successfully cope with ecological stress depended on their underlying structural characteristics.

The nature of resource entitlement channels, or the manner in which individuals alternately engaged with markets or in subsistence production to secure their livelihoods, was also not uniform across the country. Although many have emphasised the capitalistic nature of Irish society at this time (Hazelkorn 1981, 1983; Meiksins Wood 2002), it is clear from the preceding analysis that there existed remarkable continuities in non-capitalistic land tenure or 'rundale', across vast swathes of the Irish countryside during the mid nineteenth century. This is a crucial point, as it introduces the possibility for substantial variation in the ways in which individuals engaged with capitalistic markets for the sale of their surplus produce, whilst continuing to organise agricultural production in a fundamentally non-capitalistic manner. With regard to entitlement-based models of food security, it therefore becomes decidedly difficult to characterise the structure of Ireland's indirect entitlement channels, given the variety of ways in which market mediation is likely to have penetrated agricultural production at settlement level (Devereux 2001).

Although this exercise bears numerous theoretical implications, they must be advanced with a measure of caution, as the preceding exercise has relied upon data drawn from ecological units (i.e. counties). Despite the limited capacity of 'aggregate approaches' to fully account for relationships at lower levels of aggregation, the explanatory power of the social-ecological regimes identified above is no less diminished $a$ priori by the utilisation of spatial units by the analyst, with whom blame must also reside when the explanatory limitations of ecological units are breached, and projected downward onto individuals. It is therefore critical not to overgeneralise such associations, or to assume that the characteristics of individual settlements within the above regimes will necessarily display similar associations. Given a comparative lack of data at lower levels of aggregation, such limitations are unfortunately unavoidable.

By serving as an orienting device, this exercise confirms something of the exceptional nature of the peripheral western regions of nineteenth century Ireland, quantifies these regional differences, and offers a basis for subsequent local inquiry. From the preceding results, we observe merely a potential differential distribution of social-ecological resilience across the territory of Ireland, by noting areas subject to greater probabilities of ecological stress. This tells us little of the dynamics of localised social-ecological systems, or individual settlements however. Herein lies the precise appeal of a resilience approach; its conceptual approach invites qualitative investigation at lower levels of aggregation, by working from the characteristics of cases themselves, rather than deriving system dynamics from a-priori variables alone. This is a fundamentally different approach to that of cross-sectional modeling, which assumes a constant, additive effect of variables across all cases (Byrne 1998, 2005). This exercise has offered a modest starting point from which to begin assessing this uneven nature of famine, as well as a general methodological template which might be adopted in other cases, as a 'first pass' means of overcoming variable-driven explanations of food insecurity. 


\section{Appendix}

\section{Cluster analysis output}

\section{Initial Cluster Centers}

\section{Cluster}

\begin{tabular}{|c|c|c|c|c|}
\hline & 1 & 2 & 3 & 4 \\
\hline zscore: population density & -2.55204 & -.19206 & 1.18460 & 1.01252 \\
\hline zscore: poor law valuation per head & 2.52063 & -1.20268 & 1.8517 & -1.54584 \\
\hline zscore: \% females 26-35 married & -.86642 & 1.24137 & -.86642 & 1.88992 \\
\hline $\begin{array}{l}\text { Zscore: \% total waste (course } \\
\text { pasture) below } 800 \mathrm{ft} \text { above sea } \\
\text { level }\end{array}$ & -2.22270 & -.22563 & 1.04174 & .84972 \\
\hline Zscore: \% holdings 1-5 acres & -.40549 & .76592 & -.31538 & 2.74829 \\
\hline $\begin{array}{l}\text { Zscore: log original \% land held in } \\
\text { common or joint tenancy }\end{array}$ & -.23244 & -.76598 & -1.20503 & 2.34405 \\
\hline
\end{tabular}

\section{Iteration History}

\section{Change in cluster centers}

$\begin{array}{llll}1 & 2 & 3 & 4\end{array}$

Iteration

\begin{tabular}{lllll}
\hline 1 & 2.164 & 1.523 & 1.501 & 1.828 \\
2 & .756 & .213 & .340 & .616 \\
3 & .205 & .174 & .000 & .492 \\
4 & .000 & .175 & .000 & .451 \\
5 & .000 & .000 & .000 & .000 \\
\hline
\end{tabular}




\section{Final Cluster Centers}

\begin{tabular}{lcccc}
\hline & \multicolumn{5}{c}{ Cluster } \\
& \multicolumn{1}{c}{$\mathbf{1}$} & $\mathbf{2}$ & $\mathbf{3}$ & $\mathbf{4}$ \\
\hline zscore: population density & -.92779 & -.36225 & .79303 & 1.13052 \\
& & & & \\
zscore: poor law valuation per head & .68962 & -.50447 & 1.04749 & -1.12032 \\
& & & & \\
zscore: \% females 26-35 married & -.63480 & .38079 & -.93591 & 1.20894 \\
$\begin{array}{l}\text { Zscore: \% total waste (course } \\
\text { pasture) below 800ft above sea }\end{array}$ & -1.14187 & .22637 & .14196 & .81131 \\
level & & & & \\
$\begin{array}{l}\text { Zscore: \% holdings 1-5 acres } \\
\text { Zscore: log original \% land held in } \\
\text { common or joint tenancy }\end{array}$ & -.45698 & .27379 & -.65006 & .83800 \\
\hline
\end{tabular}

\section{Number of cases in each cluster}

\begin{tabular}{cc}
\hline Cluster & Cases \\
\hline 1 & 7 \\
2 & 13 \\
3 & 7 \\
4 & 5 \\
\hline Valid & 32 \\
Missing & 0 \\
\hline
\end{tabular}




\section{References}

Abel, N., Cumming, D.H.M., and Andrews, J.M., 2006. Collapse and Reorganisation in SocialEcological Systems: Questions, Some Ideas, and Policy Implications. Ecol. \& Soc. 11, 17-42.

Adger, W.N., 2000. Social and ecological resilience: are they related? Progress in Human Geography 24, 347-364.

Almquist, E., 1977. Mayo and Beyond: Land, Domestic Industry and Rural Transformation in the Irish West. Ph.D Thesis, Boston University.

Axinn, W., Ghimire, D., 2011. Social Organization, Population, and Land Use. Am. J. Sociol. 117, 209-258.

Bell, J., Watson, M., 2006. Architectural Features and Farming Practices in the Glens of Antrim. Glens of Antrim Historical Society, Antrim.

Berkes, F., Colding, J., Folke, C., (Eds.), 2003. Navigating Social-Ecological Systems: Building Resilience for Complexity and Change. Cambridge University Press.

Bourke, A., 1959. The Extent of the Potato Crop in Ireland at the time of the Famine. Statistical and Social Inquiry Society of Ireland, Paper read before the Society on October $30^{\text {th }}, 1959$.

Boyle, P.P., Ó’ Gráda, C., 1986. Fertility Trends, Excess Mortality and the Great Irish Famine. Demography 23, 543-562.

Byrne, D., 1998. Complexity Theory and the Social Sciences. Routledge, London.

Byrne, D., 2005. Complexity, Configurations and Cases. Theory, Culture and Society 22, 95111.

Census of Ireland., 1841. Report of the Commissioners Appointed to Take the Census of Ireland, for the Year 1841. 1843 [504] xxiv.

Clarkson, L.A., 1981. Irish Population Revisited, 1687-1821. In: Goldstrom, J.M., Clarkson, L.A. (Eds.), Irish Population, Economy and Society: Essays in Honour of the late K.H.

Connell. Clarendon Press, Oxford, pp. 13-36.

Connell, K.H., 1950a. The Population of Ireland, 1750-1845. Greenwood Press.

Connell, K.H., 1950b. Land and Population in Ireland, 1780-1845. The Econ. Hist. Rev. 2, 278289.

Connell, K.H., 1950c. The Colonization of Waste Land in Ireland, 1780-1845. The Econ. Hist. Rev. 3, 44-71.

Connell, K.H., 1962. The Potato in Ireland. Past and Present 23, 57-71.

Cousens, S.H., 1960. Regional death rates in Ireland during the Great Famine from 1846 to 1851. Pop. Stud 14, 55-74. 
Cumming, G.S., Barnes, G., Perz, S., Schmink, M., Sieving, K.E., Southworth, J., Binford, M., Holt, R.D., Stickler, C., Van Holt, T., 2005. An Exploratory Framework for the Empirical Measurement of Resilience. Ecosystems 8, 975-987.

Cumming, G.S. 2011. Spatial Resilience in Social-Ecological Systems. Springer Science, New York.

Currie, E.A., 1986. Settlement Changes and their Measurement: A Case Study from Co. Londonderry, 1833-1906. In: Buchanan, R.H. (Ed.), Rural Landscapes and Communities: Essays Presented to Desmond McCourt. Irish Academic Press, Dublin, pp. 93-120.

Devereux, S., 2001. Sen’s Entitlement Approach: Critiques and Counter-Critiques. Ox. Devel. Stud 29, 245-263.

Devon Commission., 1845. Appendix to minutes of evidence taken before Her Majesty's Commissioners of Inquiry into the state of the law and practice in respect to the occupation of land in Ireland. Part IV. 1845 [672] [673] xxii, Appendix 94, pp. 280-282.

Dickens, P., 1996. Reconstructing Nature: Alienation, emancipation and the division of labour. Routledge, London.

Doherty, C., 2000. Settlement in Early Ireland: A Review. In Barry, T. (Ed.), A History of Settlement in Ireland. Routledge, London, pp. 50-80.

Dowling, M., 1999. Tenant Right and Agrarian Society in Ulster, 1600-1870. Irish Academic Press, Dublin.

Downey, T., 1996. The Lumper: An Analysis of its Role in the Irish Famine, 1845-1850. Donegal Annual 48, 100-103.

Evans, E.E., 1957. The Ecology of Peasant Life in Western Europe. In: Thoman, W.L. Jr. (Ed.), Man's Role in Changing the Face of the Earth. University of Chicago Press, Chicago, pp. 217-239.

Everitt, B.S., Landau, S., Leese, M., Stahl, D., 2011. Cluster Analysis, $5^{\text {th }}$ Edition. Wiley and Sons, Chichester.

Fabricius, C., Cundill, G., 2011. Building Adaptive Capacity in Systems Beyond the Threshold: The Story of Macubeni, South Africa. In: Armitage, D., Plummer, R. (Eds.), Adaptive Capacity and Environmental Governance. Springer, Berlin, 43-68.

Fisk, D.J., Kerhevre, J., 2006. Complexity as a cause of unsustainability. Ecol. Complex. 3, 336-343.

Flaherty, E., 2013. Geographies of Communality, Colonialism, and Capitalism: Ecology and the World-System. Hist. Geog. 41, 59-79.

Fraser, E.D.G., 2006. Food system vulnerability: Using past famines to help understand how food systems may adapt to climate change. Ecol. Complex. 3, 328-335. 
Fraser, E.D.G., 2007. Travelling in antique lands: using past famines to develop an adaptability/resilience framework to identify food systems vulnerable to climate change. Clim. Change 83, 495-514.

Gray, J., 2005. Spinning the Threads of Uneven Development: Gender and Industrialization in Ireland during the Long Eighteenth Century. Lexington Books, Lanham.

Grimm, V., Calabrese, J.M., 2011. What is Resilience? A Short Introduction. In: Deffuant, G., Gilbert, N. (Eds.), Viability and Resilience of Complex Systems: Concepts, Methods and Case Studies from Ecology and Society. Springer, Berlin, pp. 3-14.

Gunderson, L., 2003. Adaptive dancing: interactions between social resilience and ecological crises. In: Berkes, F., Colding, J., Folke. (Eds.), Navigating Social-Ecological Systems: Building Resiliennce for Complexity and Change. Cambridge University Press, pp. 33-52.

Hazelkorn, E., 1981. Some problems with Marx’s theory of capitalist penetration into agriculture: the case of Ireland. Econ. \& Soc. 10, 284-315.

Hazelkorn, E., 1983. Reconsidering Marx and Engels on Ireland. Saothar 9, 79-88.

Holling, C.S., 2001. Understanding the Complexity of Economic, Ecological and Social Systems.” Ecosys. 4, 390-405.

Hooper, J. 1922. The Yields of Irish Tillage Food Crops Since the Year 1847. Department of Agriculture and Technical Instruction for Ireland Journal 21, 205-229.

Hughes, J., 2000. Ecology and Historical Materialism. Cambridge University Press.

Janssen, Marco A., Anderies, John M., Ostrom, E., 2007. Robustness of Social-Ecological Systems to Spatial and Temporal Variability. Soc. \& Nat. Resour. 20, 307-322.

Kennedy, L., Clarkson, L.A., 1993. Birth, Death and Exile: Irish Population History, 17001921. In: Graham, B.J., Proudfoot, L.J. (Eds.), An Historical Geography of Ireland. Academic Press, London, 158-184.

Kinealy, C., 2006. This Great Calamity: The Irish Famine 1854-52. Gill and Macmillan, Dublin.

Kinzig, A.P., Ryan, P., Etienne, M., Allison, H., Elmqvist, T., Walker, B.H., 2006. Resilience and Regime Shifts: Assessing Cascading Effects. Ecol. \& Soc. 11, 20-43.

Landau, S., Everitt, B.S., 2004. A Handbook of Statistical Analysis Using SPSS. Chapman \& Hall/CRC, London.

Latour, B., 2004. Politics of Nature: How to Bring the Sciences into Democracy. Cambridge University Press.

Latour, B., 2005. Reassembling the Social: An Introduction to Actor-Network Theory. Oxford University Press. 
Mac Aoidh, S., 1990. Nixon: A Tyrant Landlord. Donegal Annual 42, 45-48.

MacNeill, E., 1921. Celtic Ireland. Martin Lester, Dublin.

Matthews, R., Sydneysmith, R., 2011. Adaptive Capacity as a Dynamic Institutional Process: Conceptual Perspectives and Their Application. In: Armitage, D., Plummer, R. (Eds.), Adaptive Capacity and Environmental Governance. Springer, Berlin, pp. 223-242.

McCabe, Desmond. 1991. Law, Conflict and Social Order in County Mayo 1820-1845. University College Dublin, unpublished Ph.D thesis

McCourt, D., 1955a. The Rundale System in Donegal: Its Distribution and Decline. Donegal Annual 3, 47-60.

McCourt, D., 1955b. Infield and Outfield in Ireland. The Econ. Hist. Rev. 7, 369-376.

McCourt, D., 1971. The Dynamic Quality of Irish Rural Settlement. In: Buchanan, R.H., Jones, E., McCourt, D. (Ed.), Man and His Habitat: Essays Presented to Emyr Estyn Evans, Routledge, London, pp. 126-164.

Meiksins Wood, E., 2002. The Origin of Capitalism: A Longer View. Verso, London.

Mokyr, J., 1980. The deadly fungus: An econometric investigation into the short term demographic impact of the Irish Famine. Res. in Pop. Econ. 2, 237-277.

Murdoch, J., 2001. Ecologising Sociology: Actor Network Theory, Co-Construction and the Problem of Human Exemptionalism. Sociology 35, 111-133.

National Centre for Geocomputation. 2010. Mapping Population Change in Ireland 1841-1851: Quantitative Analysis using Historical GIS [http://ncg.nuim.ie/content/projects/famine]

O’ Neill, K., 1984. Family and Farm in pre-Famine Ireland: The Parish of Killashandra. University of Wisconsin Press.

Ó’ Gráda, C., 1994. Ireland: A New Economic History, 1780-1939. Clarendon Press.

O’ Sullivan, M., Downey, L., 2008. Post-Medieval Fieldscapes - Part 2: Rundale. Arch. Ire. 22, 22-25.

Orser Jr, C.E., 2006. Unearthing hidden Ireland: Historical archaeology at Ballykilcline, County Roscommon. Wordwell, Wicklow.

Ostrom, E., 1990. Governing the commons: The evolution of institutions for collective action. Cambridge University Press.

Rabe-Hesketh, S., Everitt, B., 2004. A Handbook of Statistical Analyses Using Stata (3 ${ }^{\text {rd }}$ edition). Chapman and Hall/CRC, New York. 
Sen, A., 1976. Famines as Failures of Exchange Entitlements.” Econ. \& Pol. Weekly 11, 12731280.

Sen, A., 1980. Famines. World Devel. 8, 613-621.

Sen, A., 1981. Ingredients of Famine Analysis: Availability and Entitlements. Quart. J. of Econ. 96, 433-464.

Slater, E., 1988. A Contribution to a Critique of the Idealisation of Irish Agricultural Development, 1847-1882. Ph.D. Thesis, Trinity College Dublin.

Slater, E., Flaherty, E., 2009. Marx on Primitive Communism: The Irish Rundale Agrarian Commune, its Internal Dynamics and the Metabolic Rift. Ir. J. Anthro. 12, 5-34.

Slater, E., McDonough, T., 2005. Colonialism, Feudalism and the Mode of Production in Nineteenth-Century Ireland. In: McDonough, T. (Ed.), Was Ireland a Colony? Economics, Politics and Culture in Nineteenth-Century Ireland. Irish Academic Press, Dublin, pp. 27-47.

Uhlig, H., 1961. Old Hamlets with Infield and Outfield Systems in Western and Central Europe. Geograf. Ann. 43, 285-312.

van Apeldoorn, D.F., Kok, K., Sonneveld, M.P.W., Veldkamp, T.A., 2011. Panarchy Rules: Rethinking Resilience of Agroecosytems, Evidence from Dutch Dairy-Farming. Ecol. \& Soc. 16, 39-57,

Vaughan, W.E. and Fitzpatrick, A.J. 1978. Irish Historical Statistics: Population, 1821-1971. Dublin: Royal Irish Academy.

Walker, B., Gunderson, L., Kinzig, A., Folke, Carl., Carpenter, S., Schultz, L., 2006. A Handful of Heuristics and Some Propositions for Understanding Resilience in SocialEcological Systems. Ecol. \& Soc. 11, 13-28.

Whelan, K., 1995. Pre and Post-Famine Landscape Change. In: Póirtéir, C. (Ed.), The Great Irish Famine. Mercier Press, Cork, pp. 19-33.

Whelan, K. (ed.), 1999. New Survey of Clare Island. Royal Irish Academy, Dublin.

Whelan, K., 2000. Settlement and Society in Eighteenth-Century Ireland. In: Barry, T. (Ed.), A History of Settlement in Ireland. Routledge, London, pp. 187-205.

Yager, T., 1996. Mass Eviction in the Mullet Peninsula During and After the Great Famine. Ir. Econ. \& Soc. Hist. 23, 24-44.

Yearley, S., 2005. Cultures of Environmentalism: Empirical Studies in Environmental Sociology. Palgrave, New York. 